\title{
African women's theology and the re-imagining of community in Africa
}

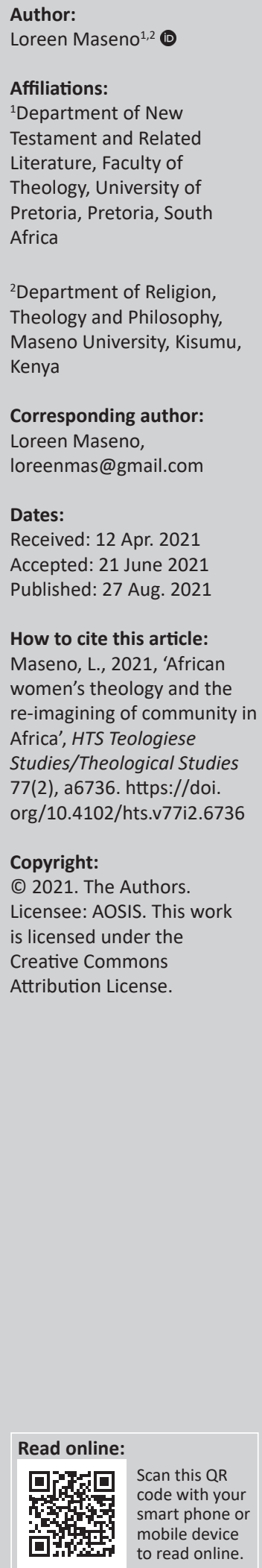

\begin{abstract}
African women's theology has a commitment to the emancipation of women covering the several themes such as ecclesiology, hospitality, community, spirituality, sacrifice, ecology and missiology. African women's theology examines African culture and demonstrates an understanding of women as a distinct group with inherent varieties within this category. Furthermore, African women's theology incorporates experiences of African women in their perspectives while analysing women's subordination. This article is a re-imagining of community in African theology. African theology has traditionally promoted the need to appreciate African culture and see to it that the integrity of African culture is upheld. However, in so doing, it laid an emphasis only on the positive aspects in African community and turned a blind eye to what was inherent in African community and not worthy to be reclaimed.
\end{abstract}

Contribution: A closer look at African women's theology provides a re-imagining of community as gleaned from Mercy Oduyoye and Teresia Hinga who assert that the quality of community in Africa ought to entail relationships, which promote reciprocity, mutuality, partnership and denounce hierarchies that promote power relations between men and women.

Keywords: African theology; African women's theology; community; re-imagining; Africa.

\section{Introduction}

African women theologians began utilising feminist approaches only in the late eighties. According to John Parratt, the earliest sustained exposition (on feminism) to come from an African woman, Mercy Oduyoye was her book titled, Hearing and Knowing (Parratt 1995:51). A reason for this is the formal theological training by African women to the high levels that was not previously possible.

African theology on community has been expressed variously by scholars such as John Pobee, John Mbiti and Charles Nyamiti among others. To these, the African emphasis on community illuminates the communal dimension of the gospel. The result of this emphasis is that Africans' contact with the gospel should increase community as it is in African culture. According to Mbiti, after an interaction with the gospel, the communal dimensions in African culture should be more enriched and deepened. The church in Africa as the community of the redeemed should be able to portray what community in African culture is (Mbiti 1972:50-52).

Mbiti addresses marriage in the context of community, as being important in fulfilling an obligation, a duty and a custom that every normal person should be married and bear children (Mbiti 1987). In African communities, it follows that failure to get married is like committing a crime against well-established community beliefs and practices. For continuity in community, the supreme purpose of marriage according to African people is to bear children, to build a family, to extend life and to hand down the living torch of human existence (Mbiti 1975:104-105).

For Mbiti, African theology considers the resurrection of Jesus as a communal event where individuality is subsumed. In its place is a corporate resurrection body. For community in Africa, the theologians John Pobee, John Mbiti and Charles Nyamiti note that a person's individuality is best fulfilled in relation to the good of others in kin group. The body of Christ as corporate resonates with communality in African culture. In addition, Mbiti sees the pre-Christian traditions of Africa as a rich heritage in which the gospel can be understood. Through the rites of passage, people are incorporated into African community (Mbiti 1972:54).

Note: Special Collection: Women Theologies, sub-edited by Sinenhlanhla S. Chisale (Midlands State University) and Tanya van Wyk (University of Pretoria). 
Re-imagining community in Africa is important because traditionally African Theology laid an emphasis on the positive aspects in African community. This was because African theologians in the wake of liberation movements were very keen to see that the cultural heritage of their people was maintained and celebrated at all cost. To them there was a need to appreciate community in African culture and see to it that the integrity of African culture is upheld. However, in doing so, African theology turned a blind eye to what in African community is not worthy to be reclaimed. African women's theology in re-imagining community demonstrates African women theologians concerns and priorities for African community. These priorities expressed by African women's theologians provide a re-imagining of community, which shall be the focus of this article. According to Oduyoye, (African) women do not accept that African men's theology only should suffice for the entire faith community. Therefore, there ought to be a study of African Christian theology in the women-centred key. This is to be understood as what highlights women as actors, agents and thinkers (Oduyoye 2001:10).

\section{Community in African theology}

According to Kanyoro, women in Africa are the custodians of cultural practices. For generations they have guarded cultural prescriptions that are strictly governed by the hesitation of breaking taboos. However, for Kanyoro, in community there are aspects that diminish women, are androcentric and continue to be practised to different degrees and make women objects of cultural preservation. These practices could be said to include lobola (the giving of bride price), forced female circumcision, polygamy and the dominantly male right to inheritance of land (Kanyoro 2001:159).

African theology has since time immemorial given significance to community, noting that community is ideal and worth keeping at all times. Often, the version of community is extolled without examining those aspects, which deny African women full humanity. In a traditional sense, African theology posits that all is well in as far as the African understanding and construction of community is concerned. For Mbiti, the African community is the place where traditional values flourish and good life abounds. In African theology, the kin group is very important and that a person's individuality is best fulfilled in relation to others and that living in community is the same for both women and men (Mbiti 1969:140-144).

It is notable that Nyamiti, Pobee and Mbiti in the wake of liberation movements seeking independence from colonialists were keen to see that the cultural heritage of their people was maintained. To them there was a need to appreciate African culture and see to it that the integrity of African culture is upheld (Nyamiti 1994; Pobee 1992). However, some scholars like Ngugi wa Thiongo, went further to romanticise it. There being no perfect culture, the effort to try to portray such a picture of African culture is unrealistic. Consequently, African theology did not pay attention to the analysis of oppressive aspects in African culture, but entirely affirmed them.

Most African cultures are patriarchal. As such, it is a society characterised by asymmetric dualisms thereby legitimising patriarchal relations of domination and subordination as 'natural difference'. Patriarchal relations often lead to the inability to relate to the cries of the underprivileged and the downtrodden. Patriarchal cultures continue to demonstrate hierarchies, competition and skewed power relations.

A statement in Mbiti's writings that best depicts communality is, 'I am because we are and since we are therefore I am' (Mbiti 1969:108-109). Mbiti notes keenly the sense of community in African culture. To Mbiti, the African emphasis on community illuminates the communal dimension of the gospel. After an interaction with the gospel, the communal dimension of African culture should be more enriched and deepened. For Mbiti, the church in Africa as the community of the redeemed should be able to portray what community in African culture is. Coming into the body of Christ, leaves room for coming with others. It is not to isolate individuals. Indeed, the emphasis is on the coming, not alone but with one's entire community (Mbiti 1972:50-55). This is similar to the 1st Century Christianity where whole households converted. Mbiti discerns a connection between African Traditional Religion and the Hebrew Bible where there is a pervasiveness of religion in all activities, rituals and community (Mbiti 1994).

According to Mbiti, the crucial events in one's life involve the whole community and especially groups of basic significance to the person. A person's kinship group according to Mbiti comprises the living, the dead and the yet to be born:

The arrival of a child in the family is one of the greatest blessings of life ... If it is the first pregnancy for her [a woman], it assures everyone that she is able to bear children. Once that is known, her marriage is largely secure and the relatives treat her with greater respect than before. (Mbiti 1975:81)

African theology interprets the resurrection of Jesus as a communal event where individuality is subsumed. In its place is a corporate resurrection body. It notes that a person's individuality is best fulfilled in relation to the good of others in kin group. The body of Christ as corporate resonates with communality in African culture. African theology considers the pre-Christian traditions of Africa as a rich heritage in which the gospel can be understood. Through the rites of passage, people are incorporated into community. He points out that the birth of Jesus, his baptism (initiation) and his death correspond to the main rites of passage in traditional religion (Mbiti 1972:54).

African theology also asserts that Jesus as a human being fully participated in the human community. According to John Pobee, Jesus brings humans into a new community, his body. This new community transcends the old clan, family and tribe, giving way to the totality of the community of the 
church, which is in true keeping with African notions (Pobee 1979:98).

\section{Norms for African women's theology}

African religio-cultural heritage provides insights that are appropriated by the African women theologians. There are written sources that are a useful source for African women's theology from the $\mathrm{Circle}^{1}$ articles and book publications (Pemberton 2003). Another norm and source for African women's theology is the Christian feminist movement of the west. According to Kanyoro (2001):

[F]eminist methodology is used because it challenges cultural socialisation and rejects the assumption that the roles of women and men have already been fixed, either by the creator or by the culture. (pp. 158-180)

Feminist theology, after originating from the west, has been accessed by women theologians in Africa through writings and academic forums. Indeed, feminist theology in Africa, as mentioned earlier, has developed because of African women's association with institutions, ideas and access to publications from the west.

African women's theology draws much from another norm and source, which is women's experience. Their context and experience are critical because they do not write theology that is remote and removed from their daily living (Oduyoye 2001). They grant that there are unique experiences and insights that come from individuals in their contexts. For this reason, an additional norm and source for African women's theology is African women's experience. Some of these experiences include African women theologians' experiences or those that they have heard from the experiences of others on issues such as women labourers, sexual exploitation, oppressive hierarchical structures in the churches, oppressive customs and marriage structure. The theologian Sheila Davaney asserts that, women's experience as the norm arose because of its privileged character. This privilege arises from claims about women's status and ontological nature coupled with women's historical experience of oppression (Davaney 1997:200).

The bible is a norm and a source for African women's theology. Most of the African women theologians are keen churchwomen, some of whom are ordained into the Eucharist ministry while others are laywomen (Maseno \& Mligo 2019:32). For the African women theologians, the bible is central in their theologising. However, the bible cannot be the only norm because, 'any interpretation of the bible is unacceptable if it does harm to women, the vulnerable and the voiceless' (Oduyoye 2001:12).

1.The Circle was founded on the 25 September 1989 in Accra, Ghana. The Circle is a Africa. It is a not ive outside Africa. It is a voluntary movement whose work often takes place within regiona meetings. The Circle was inaugurated in order to facilitate the writing, research and publication by a Pan-African multireligious and multiracial network of women. There is a consensus in Africa that the Circle is representative of African women's theological perspectives. Any representative coverage of African women's theology must take into consideration the Circle.
However, the bible is not the only norm. While bearing on hermeneutical analysis of the bible in Africa, theological reflection is complemented by other sources such as stories, folklores and legends (Oduyoye 1996). Narrative theology prevails in both oral and written materials. Stories play a normative role in Africa and therefore are a source for theology. These norms and sources allow that clear reflection is made by scholars in African women's theology.

In what follows is a textual analysis of the works of two African female theologians. Both are committed to the emancipation of women and to incorporating women's experience in their analysis. My criteria for selection were that from the two women theologians one has to be from West Africa and the other from East Africa. Both also have to be active members of the Circle of Concerned African Women Theologian. Furthermore, they merit consideration because they are part of the organising caucus of the Circle made up of 10 African women theologians (Pemberton 2003:15).

\section{Re-imagining community in African women's theology: Perspectives from Teresia Hinga}

The theme of community is explored by many African women theologians because of their sense and responsibility for extended families and the respect accorded to ancestors.

Teresia Hinga notes that the distinct history of Africans is a history that is marked by colonialism, therefore the cultural context from which African women theologians speak is distinct (Hinga 1992b). Hinga considers the consciousnessraising of African women as a subjugated group therefore becomes a process by means of which women are liberated and a process that awakens them to participate in the process of human liberation in general (Hinga 1999:44). Consequently:

A society or [a community] is one where there is an eradication or correction of patriarchy which often leads to women being discriminated against, oppressed and exploited because of their sex. In a society or community, there needs to be an unmasking of sexual injustices and their subsequent elimination in order to bring about the liberation of women... It is with legitimation that women should take up the challenge of social transformation, unmasking and eradicating social injustices to pave the way for the eschatological community that the bible looks forward to. (Hinga 1999:43)

For Hinga, it is important in African community to correct sexual injustices in society and community. She notes that there are social injustices experienced by African women because of patriarchy in African communities. These lead to women being discriminated against their effort to be enjoined in the communities in which they find themselves (Hinga 2002). In addition, Hinga is aware and calls out sexual injustices in communities that are to be eliminated for the ideal community to be experienced (Hinga 1992a). 
Hinga acknowledges the possibility of oppressive human relationships in community. Many women in Africa have gone through injustices such as domestic violence (Hinga 1994) and should be able to unmask and name these oppressive elements. This is what African women's theology avails in the re-imagination of community, which should be transformative and liberating for women and men alike.

For Hinga, African women have to partake in their own liberation:

The task of self-liberation therefore involves dialogue rather than war with the oppressor. This however, does not mean that women as the oppressed turn a blind eye to oppressive relationships. In fact, it is their task to unmask, name and denounce all aspects that they find oppressive to human relationships...liberation is not only a privilege to be enjoyed by the oppressed women, but it is also a task to be done. Women therefore are called not only to be recipients of liberation to enjoy the privilege of liberation, but also to be challenged to become subjects, by actively undertaking the task of liberating, transforming, not only themselves but also society to ensure a more humane and egalitarian future. (Hinga 1999:44-45)

\section{Re-imagining community in African women's theology: Perspectives from Mercy Oduyoye}

According to Oduyoye, African women theologians explore community and also pay attention to the household of God and the words of women that are critical in African women's theology (Oduyoye 2001:20). Oduyoye examines community in Africa and asserts that, the real disease in human relationships is rooted in the perverse patriarchalisation of life (Oduyoye 1994a:177). She also states:

$[D]$ o not let African men tell you that African women do not need to speak of oppression, nor allow them to define what is the real source of oppression for African women. (Oduyoye 1989:442)

For Oduyoye, there ought to be a separation of men's and women's interests and explanations of issues.

In considering community in Africa, Oduyoye laments that the woman is the one who moves from one community to another and that at the same time there is no real power that resides in the hands of the woman (Oduyoye 1986:123). She notes that young women in today's Africa continue to see themselves and are seen by African males as somehow owned by their men who support them (Oduyoye 1986:122). She notices that the African woman is placed at a lower level because of the hierarchies of patriarchy. As a result, in most African societies, females cannot be autonomous. Their identity is completely constructed in relation to others.

In order to fit into the community, the unspoken assumption is that a woman must be married. A young person's maturity is fully recognised with marriage (Oduyoye 1993). This is especially seen in the performance of the marriage ritual, which emphasises the transfer of the woman from the spiritual power of the father to that of the husband (Oduyoye 1992:1315). The pressure and strain of some community norms and expectations piles on many women who remain unmarried and many end up getting into such estates only to appease members of the wider family:

In the process of the noble battle to maintain the institution of the family, women's personal development is curbed because their domestic labours are required by the male folk to make their own participation and progress in the modern labour force possible and comparatively easy. (Oduyoye 1994b:33)

\section{Oduyoye further observes that in Africa:}

Most communities have intentional educational events, which take place throughout childhood but specifically at the threshold of adulthood, in what has become generally known as initiation rites. The result of this socialization, and especially as related to the latter, is that African women are programmed to live for others. They live for children, family and community as these constitute the locus of one's worthiness. This in some cases has come to mean that women live to please men and pride themselves with being providers of continuity and the carriers of tradition. (Oduyoye 2001:31)

According to Oduyoye, to live in community is to do so in partnership and reciprocity. The ordering of the human community should not be only performed by either the males or the females. In reciprocity within the community, women should not monopolise the servant role (Oduyoye 1994a:178). Oduyoye shows that there is a necessity for African men to understand the idea of sacrifice for the ordering of human society, and that within community in Africa, relations between men and women are distorted. To her, African women traditionally believe in the worth of sacrifice for the community. If sacrifice is taken seriously, it can lead to social reforms and a feeling of ultimate dependence on what she calls the SourceBeing(God).However, Oduyoyehas a probleminunderstanding why it is the prerogative of only one sex to sacrifice for the wellbeing of the community (Oduyoye 1983b:112).

Oduyoye refers to the narrative in the Garden of Eden, in Genesis 3:1-7. According to Oduyoye, Adam completely forgets his responsibility to God who commanded. When Eve decided to experiment and to persuade Adam, he was an unquestioning collaborator who yielded to the demands of another (Eve). According to Oduyoye, the male principle in the world, instead of seeking community attempts to forestall, being an unquestioning follower. Therefore, the Genesis account, according to her condemns hierarchy that undermines community and ignores individuals' ability to contribute.

For Oduyoye, neither domination nor acquiescence in human relations can make for a healthy community (Oduyoye 1986:93-95). God created women and men equally human, made them stewards of creation and gave them authority to manage it, jointly. She notes that the one sided development of the source of human authority has reduced stewardship to domination, husbanding to control and complementarity to the paternal determining the scope of being for the maternal (Oduyoye 1990:53). 
Oduyoye further mentions that sexist criteria cripple and tend to subsume the woman under the man suggesting that we believe the needs of the males are more important than those of the whole community. However, the community transcends the joint existence of both composite parts. Consequently, the terms of interaction ought to be evolved by both partners (Oduyoye 1986:129).

Showing dissatisfaction at the way relationships in African community have been, Oduyoye wonders whether human societies must be either patriarchal or matriarchal. She wonders whether mutuality is out of question and why relationships cannot be seen in the lines of mutual interest, trust and responsibility. For her what is noticeable is broken communities as can be seen in separate development and job appointment among women and men (Oduyoye 1986:133). To Oduyoye, gender is no criterion for the lack or possession of wisdom. As we are all equally responsible for our community, a person's word must be listened to and assessed alongside that of others (Fabella \& Oduyoye 1988:49). Oduyoye further demonstrates that men override culture when it does not suit them or are conservative when it suits them... African women realise that the reciprocity demanded by culture on the other levels does not apply between men and women yet women continue to pursue it (Oduyoye 1994a:175-176).

\section{Reflections on community in Africa}

African theology is appreciated as enabling African theologians share African ideals. Although it presents a valuable collection of popular beliefs and practices in Africa, it is strangely silent about negatives inherent in African community life. With the strict division of labour in many African traditional communities how does African theology on community relate to the work of women or to childcare? Who speaks for the silenced in the community, those who have been taught to be seen and not be heard? What does it mean not to be permitted to be vocal like most women and children in patriarchal communities?

African theology does not indicate the dynamics that are involved in trying to remain in community, where patriarchy is the order of the day and the womenfolk are relegated to an inferior status. For Mbiti, what is important and what the African religiosity should contribute to Church development in general is communality. This in itself is not bad, however, the issue to be advanced is rather, 'what quality of community' should be proposed. What African theology offers are simplistic and romanticised accounts of community life. In effect, what it does is to present African communities as harmonious groups of persons bonded together (Maseno 2020:42-43).

In African theology, the African community is the place where traditional values flourish and good life abounds. Thus, it tends to focus on the stability and unity of African communities and traditions over time. However, a closer look at communities would indicate a surface stability that often hides practices of violence and exclusion. In general, African theology fails at the level of normative reflection because it tends to uncritically promote social values that reflect the status quo and depict patriarchal cultural values. By defending communal values simply because they are communal and traditional in nature, African theology has difficulty establishing self-criticism within communities (Maseno 2020:44).

In general, African theology on community is wanting, because it equates the experience of a man in African community to that of a woman in African community. They are not the same and thus unacceptable. The male perspective has been used and understood as the human perspective therefore, lacks input from a female perspective. The dominant contributors to African theology on community have been perceived to be speaking on behalf of all African people. The experience of women has not been utilised in the quest hence denying a more comprehensive and just approach (Maseno 2020:45-46).

African women's theology highlights that in many patriarchal societies, it is women who take place under the menfolk. Thus, subordination cannot take place without there being a power relation. Attesting to the place of women in Africa, Hinga and Oduyoye describe the subordinate place of women in the power dynamic and that experience diminished control over their lives (Oduyoye 1983a).

African women are subordinated in various ways. From Hinga's work, subordination of women is exemplified by their years of forced silence that has led many to acquiescence with the various oppressions. Oduyoye points out how no real power lies in the hands of the woman and that for some, being a husband has been reduced to control, while stewardship has been reduced to domination. These theologians perceive women's subordination in their contexts and then use it in their theologising.

It is clear from the foregoing that a bias that privileges the men to the disadvantage of women has permeated African societies and to attest to true community in the light of sexism would be unrealistic. Community as such has been deluded. In re-imagining community, African women's theology insists that it is not enough to speak of community in Africa as an integral part of African culture, if the quality of community is not analysed and deemed worthy in terms of promoting justice and support for women.

\section{Conclusion}

African women's theology as exemplified by Oduyoye and Hinga, re-imagine community as those with relationships that embrace reciprocity, mutuality, partnership and denounce hierarchies that promote power relations between men and women. African women's theology asserts a relationship with African men. In this theology, women work in cooperation with men of good will for the reconstruction 
of a cultural and religious praxis of equality. But this theology also emphasises the necessity of critiquing culture and religion from the perspective of Christ as the norm for the fullness of the human being (Oduyoye 1990:27).

Community in African Theology has been critiqued by African women theologians who have aptly provided suggestions and inroads into how a fair, just and better community can be envisioned in the 22nd century. These insights are valuable in as far as women's experience is a norm and source for African women's theology and is consequently utilised by women theologians.

African theology maintains that the kin group is very important and that a person's individuality is best fulfilled in relation to others. Furthermore, living in community is the same for both women and men, which according to African women's theology is not realistic. African theology falls short of indicating the dynamics that are involved in trying to remain in community, where patriarchy is the order of the day and the womenfolk are relegated to an inferior status. For African women's theology, it seems critical that the quality of community advanced encourages mutuality and partnership void of hierarchical relations. Taking this cue, African women theologians are thus, no longer spoken for, not voiceless, rather they are well able to voice their input, which should find a place on the table as other perspectives drawn upon by African male theologians.

\section{Acknowledgements Competing interests}

The author declares that she has no financial or personal relationships that may have inappropriately influenced her in writing this article.

\section{Author's contributions}

L.M. is the sole author of this article.

\section{Ethical considerations}

This article followed all ethical standards for research without direct contact with human or animal subjects.

\section{Funding information}

This research received no specific grant from any funding agency in the public, commercial or not-for-profit sectors.

\section{Data availability}

Data sharing is not applicable to this article as no new data were created or analysed in this study.

\section{Disclaimer}

The views and opinions expressed in this article are those of the author and do not necessarily reflect the official policy or position of any affiliated agency of the author.

\section{References}

Davaney, S., 1997, 'Continuing the story, but departing the text: A historicist interpretation of feminist norms in theology', in R. Chopp \& S. Davaney (eds.), Horizons in feminist theology: Identity, tradition, and norms, pp. 198-214, Fortress Press, Minneapolis, MN.

Fabella, V. \& Oduyoye, M.A. (eds.), 1988, With passion and compassion, Orbis Books, Maryknoll, NY.

Hinga, T., 1992a, 'Jesus Christ and the liberation of women in Africa', in M. Oduyoye \& K. Kanyoro (eds.), The will to arise: Women, tradition, and the Church in Africa, pp. 184-193, Orbis Books, Maryknoll, NY.

Hinga, T., 1992b, 'An African confession of Christ: The Christology of Legio Maria church of Kenya', in J.S. Pobee (ed.), Exploring Afro-Christology, Peter Lang, Bern.

Hinga, T., 1994, 'Violence against women: A challenge to the church', in H. Kinoti \& D. Waruta (eds.), Pastoral care in African Christianity: Challenging essays on Pastoral theology, pp. 117-133, Acton Publishers, Nairobi.

Hinga, T., 1999, 'The biblical mandate for social transformation: A feminist perspective', in J. Mugambi \& A. Nasimiyu (eds.), Moral and ethical issues in African Christianity: A challenge for African Christianity, pp. 37-48, Acton Publishers, Nairobi.

Hinga, T., 2002, 'African feminist theologies, the global village, and the imperative of solidarity across borders: The case of the circle of concerned African women theologians', Journal of Feminist Studies in Theology 18(1), 79-86.

Kanyoro, M., 2001, 'Engendered communal theology: African women's contribution to theology in the 21st century', in N. Njoroge \& M. Dube (eds.), Talitha Cum!: Theologies of African women, pp. 158-180, Cluster Publications, Pietermaritzburg.

Maseno, L., 2020, 'African women theologies', in C. Kaunda and J. Gathogo (eds.), African theology, philosophy, and religions: Celebrating John Samuel Mbiti's contribution, pp. 39-51, Rowman and Littlefield, Lanham, MD.

Maseno, L. \& Mligo, E., 2019, Women within religions: Patriarchy, feminism and the role of women in selected world religions, pp. 39-51, Wipf and Stock, Eugene, OR.

Mbiti, J., 1969, African religions \& philosophy, Heinemann, London.

Mbiti, J., 1972, 'Some African concepts of Christology', in G. Vicedom (ed.), Christ and the younger churches: Theological contributions from Asia, Africa and Latin America, pp. 51-62, SPCK, London.

Mbiti, J., 1975, Introduction to African religion, Heinemann, London.

Mbiti, J., 1987, Love and marriage in Africa, Longman, Harlow.

Mbiti, J., 1994, 'The bible in African culture', in R. Gibelini (ed.), Paths of African theology, pp. 27-39, Orbis, Maryknoll, NY.

Nyamiti, C., 1994, 'Contemporary African Christologies: Assessment and practical suggestions', in R. Gibellini (ed.), Paths of African theology, pp. 67-77, SCM Press, London.

Oduyoye, M., 1983a, 'Reflections from a third world woman's experience and liberation theologies', in V. Fabella \& S. Torres (eds.), The irruption of the third world: Challenge to theology: Papers from the fifth International conference of the Ecumenical association of third world theologians, pp. 246-265, August 17-29, 1981, New Delhi, India, Orbis Books, Maryknoll, NY

Oduyoye, M., 1983b, 'The value of African religious beliefs and practices for Christian theology', in K. Kubi \& S. Torres (eds.), African theology en route, pp. 109-116, Orbis Books, Maryknoll, NY.

Oduyoye, M., 1986, Hearing and knowing: Theological reflections on Christianity in Africa, Orbis Books, Maryknoll, NY.

Oduyoye, M., 1989, 'Christian feminism and African culture: The hearth of the matter', in $\mathrm{M}$. Ellis \& O. Maduro (eds.), The future of liberation theology, pp. 441-449, Orbis Books, Maryknoll, NY.

Oduyoye, M., 1990, Who will roll the stone away? The ecumenical decade of the churches in solidarity with women, World Council of Churches, Geneva.

Oduyoye, M., 1992, 'Women and ritual in Africa', in M.R. Kanyoro \& M.A. Oduyoye (eds.), The will to arise: Women, tradition and the church in Africa, pp. 9-24, Orbis Books, Maryknoll, NY.

Oduyoye, M., 1993, 'A critique of John Mbiti's view on love and marriage in Africa', in Religious plurality in Africa, pp. 341-366, De Gruyter, New York, NY.

Oduyoye, M., 1994a, 'Feminist theology in an African perspective', in R. Gibellini (ed.), Paths of African theology, pp. 166-181, SCM Press, London.

Oduyoye, M., 1994b, 'Reflections from a 3rd world woman's perspective: Women's experience and liberation theologies', in U. King (ed.), Feminist theology from the third world: A reader, pp. 23-34, SPCK, London.

Oduyoye, M., 1996, Daughters of Anowa: African women and patriarchy, Orbis Books, Maryknoll, NY.

Oduyoye, M., 2001, Introducing African women's theology, Sheffield Academic Press, Sheffield.

Oduyoye, M. \& Fabella, V. (eds.), 1988, With passion and compassion: Third world women doing theology: Reflections from the women's commission of the ecumenical association of third world theologians, Orbis Books, Maryknoll, NY.

Parratt, J., 1995, Reinventing Christianity: African theology today, Eerdmans, Grand rapids, MI.

Pemberton, C., 2003, Circle thinking: African women theologians in dialogue with the west, Brill, Leiden.

Pobee, J., 1979, Toward an African theology, Abingdon, Nashville, TN.

Pobee, J., 1992, Skenosis: Christian faith in an African context, Mambo Press, Gweru. 